\title{
Role of Nongovernmental Organization in Bangladesh. Are They Challenging the Government Power? A Case Study from Bangladesh Rural Advancement Committee (BRAC)
}

\author{
Medani P. Bhandari \\ Professor and Deputy Program Director of Sustainability Studies, Akamai University, Hawaii, USA, Inter- \\ national Program Director, Atlantic State Legal Foundation, NY, USA, Executive Director, Human Survival \\ Foundation, Glasgow, UK
}

\begin{abstract}
In the first part of this write up the author introduces Bangladesh, explores some of the important NGOs, evaluates their contribution to national building and in second part he examines the role of BRAC Bangladesh as a case study in poverty eradication and public service delivery. In the case study, first the author outlines the historical account of BRAC and secondly its motivation to fight against the poverty through its rural development programs (credit and other), health and education and social development of Bangladesh and examine the ground of increasing power of NGOs and diminishing the government power. This study is based on the interviews and fieldwork data conducted in July and August 2007 and updated in 2016. Additional information is based on annual reports of respected NGOs of Bangladesh and reports publish by the Government of Bangladesh, the World Bank, international agencies and scholars. The purpose of this study is to examine how NGOs involve in public service delivery and how nonprofit organizations diminish the states power. This article reveals that Bangladeshi big NGOs are not totally nonprofit organizations because they are operating several business enterprises, and also diminishing the state power through public service delivery. This write up also shows that the reason of proliferation of NGOs in Bangladesh is government's inefficiency in public service delivery. Empirical evidences show that state acknowledges the role of NGOs in socio-economic development of the nation and has been trying to develop collaborative approach for development. NGOs power is not only increasing due to their efficiency in service delivery but also due to the donors' interests, and neo-liberal globalized world order. Bangladeshi NGOs have gain worldwide reputation and global attention. NGOs (i.e. Grameen Bank, BRAC, ASA, PROSHIKA) have own donors' consortium. As consequence, there are hundreds of research monographs (from World Bank, Asian Development Bank, DFID, NOVIB, Bangladesh Government etc.), doctoral dissertations (by the students from Bangladesh and abroad) and international journal articles which explore the role of NGOs in Bangladesh, their power struggle with government and accountability, transparency issues as well as their strength at both local, national and international levels. This study supports the notion that NGOs power has been increased because of the inefficiency of government in providing goods and services to its citizens. BRAC case study shows that NGOs in Bangladesh are diminishing government power not only at local and national levels but also gaining creditability in the international arena.
\end{abstract}

Keywords: NGOs, INGOs, donor agencies, governance, microcredit, woman empoerment, rural development, non-formal education, institutional building, motivation.

JEL Classification: I21, L31.

(C) The Author, 2017. This article is published with open access at ARMG Publishing.

\section{Introduction}

Bangladesh became an independent nation in 1971 following the nine months of war with Pakistan, which consists 147,570 square kilometer deltas area, lies between $20^{\circ} 34^{\prime}$ and $26^{\circ} 38^{\prime}$ north latitude and between $88^{\circ} 01^{\prime}$ and $92^{\circ} 41^{\prime}$ east longitude, and boarders with India from north and west, with Bay of Bengal from south and India and Burma form east. Bangladesh is one of the poorest country in the world the population of which consists of 168 million people (estimated 2015), with the 50\% of population below the poverty line, $26 \%$ of total population comprises urban population with an average life expectancy of 64 years; $54 \%$ of infant mortality per 1000 birth; and have the literacy rate $-47 \%$; 88\% of population follow the Muslim 
religion, 98\% people speak Bangla language; and agriculture sector generates $63.2 \%$ of total national employment (BBS, 2006; World Bank, Bangladesh at a glance, 2007; 2016 ${ }^{1}$ ).

Administratively Bangladesh is divided into six major divisions, 64 districts, 508 sub districts and 4466 unions. Bangladesh has four metropolitan cities and 119 municipalities. The capital of Bangladesh 'Dhaka' is highly populated city where more than 118,13728 people live (data in 2006), followed by Chittagong 409,0809 people, Khulna - 132,3071 people and 737,336 people live in Rajshahi respectively (Statistical pocket book, 2006). The Government of Bangladesh has a chain of networks to govern the state and provide the service to its citizens. Country has been facing various challenges such as extreme poverty, population growth and natural disasters (floods, cyclones). Bangladeshi also face problem of political instability. As a result, citizens do not get desired goods and services from the government. However, the government, various international organizations, multilateral donors, national organizations, civil society, nongovernmental organizations have been working for socio-economic development of Bangladesh. Most importantly, the nongovernmental organizations (NGOs) have gained the faith for their voluntary contribution and the public service delivery from its citizens; the government, international community and NGOs are considered as important stakeholders for the social change (World Bank, 2005).

\section{The data and methodology}

The data for this study come from primary and secondary sources. Primary data were collected through the fieldwork in July and August 2007 and updated in 2016; and secondary data were combined from annual reports and homepages of NGOs and reports by the government of Bangladesh and international agencies (World Bank, Asian Development Bank, DFID etc.). During the field visit to BRAC, seven extensive open ended interviews were conducted with senior officials, including executive director and program directors of different departments. Two group interviews were conducted with midlevel program staffs at BRAC office premises, followed by several telephone and email interviews with the staff of communication department. The BRAC project site was observed and interviews were taken with locals who were benefiting from BRAC (with the help of interpreter). In addition to BRAC, we visited ASA, PROHISKA and Kumudini's offices to get general overview of their programs. A short interview was conducted with the director of $\mathrm{Ku}$ midini at his office.

\section{General history of civil society in Bangladesh}

There is a long tradition of volunteerism in Bangladesh but no exact record how and when volunteer organizations and civil society organizations began public service delivery. However, recorded evidences is available since the $13^{\text {th }}$ century, which show that health, education and financial assistance to the needy people was in practice even before when Muslim invaded Bangladesh in the $13^{\text {th }}$ century (Hasan, 1992). Samiul Hasan (1993) notes that droughts, floods, typhoons, and tornadoes hit Bangladesh on a regular basis, there was a system to help each other to cope with the calamities since people began to stay in this largest delta. Though, those service delivery societies were informal forms of social organizations. The history of organized voluntary organization in Bangladesh, the Baptist Missionary Society, goes back to 1794. Some other voluntary organizations were subsequently established in 1800, 1903, and 1922 in order to provide medical treatment, education, and spiritual teachings to the rural poor" (p. 93). This tendency of volunteer organizations growth was even in the British colonial period (1757-1947) through Pakistani role (1947-1971) to Bangladesh, which continued after gaining independence in 1971. The first formal indigenous voluntary organization aimed at development was established in Bangladesh in 1944 following the Bengal famine of 1943, which took three million lives (p. 94). The Kumudini Trust was formalized by Rai Bahadur Ranada Prasad Shaha in 1943. Hasan et al. (1992) note that until 1947, there were 7 such volunteer organizations, from 1947 to 196869 new organizations were founded, this trend continued from 1969 to 1971, 71 new organizations were established. When country became independent in 1971, people thought that the government will be able to provide public goods and services; therefore, from 1972 to 1975 only 60 new organizations were founded. However, soon after the independent civil society leaders realized that government could not meet the expectations of people, new organizations began to form and that tendency still continues in Bangladesh. "The altruistic motives of people working in NGOs can overcome the incompleteness of contracts... One advantage that NGOs may have over the public sector is the freedom of fixed rules of civil

\footnotetext{
1 http://devdata.worldbank.org/AAG/bgd_aag.pdf; http://documents.worldbank.org/curated/en/264111487858247532/pdf/112979WP-PUBLIC-WB-Project-Profiles-7Feb17.pdf.
} 
services or standard operating procedures." "The donor enthusiasm has led to a massive proliferation of NGOs, many of them not all that motivated by altruism... [The motives of NGO leaders] may be the same as those of a for-profit firm - requiring the same monitoring and care in contract enforcement" (World Bank, 2003, p. 104). The World Bank's altruism notion fits the Bangladeshi case.

Samiul Hasan et al. (1992) note that "the government failed to solve the problems of Bangladesh and as a result the army took over in 1975. The failure of the previous government and the involvement of the army in the politics provided altruistic people with a momentum to do something to improve the lot of the common people" (p. 198). After 1971 this trend increased rapidly and still accelerates. Hasan et al. (1992) note that the reason of emergence of voluntary organizations in Bangladesh is directly related to the failure of governments to meet the hopes and aspiration of people (p. 197). The mushrooming of NGOs took more speed from 1990 (Devine, 2003, p. 230)ㄹ․ The increasing trend continues even today.

One of surprising notions reveals from the Bangladesh case that none of authoritative government tried to ban or stopped the civil society movements, while the most cases shows that authoritative governments first ban the civil society movements. In the same time, when an absolute monarchy was in practice in Nepal (1951-1990), the functions of civil society organizations were either banned or strictly supervised by the government authority. Similar examples can be traced from the communist regimes of Asia, the Soviet Union, Middle East or Africa and Latin America.

\section{The major NGOs in Bangladesh}

The World Bank (2005; 2007; 2017) notes "In Bangladesh, the civil society includes (1) approximately 45,000 clubs, local-level organizations, religious organizations, foundations and development-oriented NGOs which are registered with the Department of Social Welfare; (2) national and local trade unions, professional and business associations, and (3) numerous local community-based organizations (CBOs), including savings, religious, community development or social welfare groups, many of which may be temporary and informally constituted" (p. 28). World Bank reports shows that at least 1100-1200 nongovernmental organizations were receiving foreign funds in 2004-2016. This general notion gives how Bangladeshi NGOs are influential and able to convince foreign donor to fund their projects. Out of them major NGOs such as the Association for Social Advancement (ASA was founded in 1978, it has 4.18 million borrowers, and owns ASA University), the Bangladesh Rural Advancement Committee (BRAC was founded in 1972, it owns University, Bank and national wide business enterprises), Grameen Bank (it was founded in 1983), PROSHIKA (founded in 1976, operates in 187 development centers, covers 18,898 villages, and 1575 slums in 57 districts, it works with 1.22 million women and 111,840 primary groups for consultations, with 1 million through its microcredit programs has own donor consortia CIDA, NOVIB, DFID, European Commission, who contribute about $20 \%$ of its budget).

Likewise, Nijera Kori (we was formed in 1980, has 232,228 group members, it operates in 18 districts of Bangladesh). Nijera Kori has different approach than other NGOs in Bangladesh. They state that "At a time when Bangladesh has become famous for its innovations in the arena of microcredit, Nijera Kori continued with its principle of 'we-don't-do-credit'. Nijera Kori believes that microcredit cannot and does not reach all sections of society - especially neglected communities and people, who need it the most. Nijera Kori realizes that microcredit, as a financial institution, has succeeded in creating dependencies and vulnerabilities among communities that have used it" (Annual report 2005 and home page ${ }^{3}$ ). Another NGO working in public service sector is Palli Karma Sahayak Foundation (Rural Employment Support Foundation: PKSF founded in 1990, gets funding from funds from the GOB, the IDA/World Bank, the USAID, the Asian Development Bank (ADB) and the International Fund for Agricultural Development (IFAD), its working modality is different than in other organizations, its works through partner organizations (PKSF) has 248 working partners (the report was published in April, 2006). Another very old NGO which is normally ignored by the media is Kumudini Welfare Trust which was founded in 1943, by a First World War Veteran Rai Bahadur Ranada Prasad Shaha. Late Shaha contributed all personal and inherited property to the Trust and began to provide public services basically the free health care to the needy people, which still continues. Kumudini has 1500 permanent staff and hires about 5000 in seasonal basis to conduct its health care programs, Village Outreach Program, and women empower training programs. This NGO also has enterprises to support its

\footnotetext{
${ }^{2}$ http://www.asianphilanthropy.org/countries/bangladesh/size.html.

${ }^{3}$ http://www.nijerakori.org/index.php?option=com_content\&task=view\&id=19\&Itemid=28.
} 
programs such as Jute Trade, Jute Godowns \& Jute Baling Press, Bengal River Service (BD) Ltd, Kumudini Garments, Kumudini Pharma Ltd, Kumudini Trading.

Table 1. The percentage of NGOs that raise awareness in selected subjects

\begin{tabular}{|l|c|c|}
\hline \multicolumn{1}{|c|}{ Subject } & Big NGOs $(\%)$ & Small NGOs \% \\
\hline Sanitation & 76.90 & 79.52 \\
\hline Other health issues & 69.31 & 76.89 \\
\hline Nutrition & 68.28 & 72.51 \\
\hline Human rights & 62.57 & 57.32 \\
\hline Gender issues & 54.44 & 57.33 \\
\hline Arsenic & 49.76 & 60.79 \\
\hline Conservation & 40.50 & 44.11 \\
\hline HIV/AIDS & 39.97 & 40.81 \\
\hline Other & 32.25 & 27.40 \\
\hline Road safety & 24.34 & 24.61 \\
\hline
\end{tabular}

Source: Varun Gauri and Julia Galef (2005) (this trend still applies).

This table gives the general scenario of how big NGOs and small NGOs are involved to raise the awareness of the public in Bangladesh. The efficiency of small NGO in awareness generation seems more powerful than the big NGOs like BRAC, ASA, Grameen Bank, PROSHIKA, Nijera Kori and PKSF etc.

There are hundreds of such NGOs in Bangladesh who are contributing to change the face of Bangladesh. Many of them are worthy enough to be used in case studies. The most influential NGOs which have global influences are Grameen Bank, BRAC, ASA and PROSHIKA. Their workings modalities are well-known in the developing world and have been copied and implemented in various countries of Asia, Africa and Latin America. Most importantly BRAC has extended its own program to other Asian developing countries such as Sri Lanka, Nepal and Afghanistan as well as to African countries such as Uganda, Tanzania and southern Sudan (BRAC, 2016).

\section{History of BRAC Bangladesh}

BRACK provides public services to the Bangladeshi in health and rehabilitation sector. "BRAC, a national, private organization, started as an almost entirely donor funded, small-scale relief and rehabilitation project initiated by Fazle Hasan Abed to help the country in overcoming the devastation and trauma of the Liberation War and focused on resettling refugees returning from India. Today, BRAC has emerged as an independent, virtually self-financed paradigm in sustainable human development. It is one of the largest Southern development organizations employing 108,741 people, with $61 \%$ of women, and working with the twin objectives of poverty alleviation and empowerment of the poor" (Annual report 2006, and BRAC, 2007, 2013, 2016).

\section{Foundation}

The Bangladesh Rehabilitation Assistance Committee (BRAC) was founded in 1972 as a relief and rehabilitation work after the end of liberation war with Pakistan in 1971. In 1973 it changed its name to the Bangladesh Rural Advancement Committee (still BRAC as an abbreviation). By 1975, it introduced research and evaluation divisions in the sense that it began to examine its own work and direction taken. The same year it began women development program as well as integrated development project in Bangladesh. In 1975, BRAC began targeted development approach through the formulation of village organization, and initiated staff training program with the establishment of Training and Resource Center (TARC). In the same year, the BRAC sericulture program began employment generation for poor women of Manikgang district along with the handicraft marketing outlet. This was the first program which focuses on self-sustain of BRAC. Executive director of BRAC, Dr. Mahabub Hossain, who is an internationally renowned development economist, states that "BRAC focus was for sustainability from the initial phase of its development, which continues since 1975" (in an interview to M).

In this context, it is interesting to note that the sustainability concept was in the developing world even before the concepts came in discussion in the Western world. The empirical evidences show, that the notion of sustainability emerged during the 1970s and 1980s, for which the UN Stockholm Conference on the Human 
Environment in 1972 gave a major foundation to foster this idea. The participant of the Stockholm conference realized that harming the environment puts humans at risk. The applicability of this notion only began after the UN-sponsored Brundtland Commission released Our Common Future in 1987. The program formulation based on sustainable development came on practice only after the Rio de Janeiro UN Conference on Environment and Development in 1992. However, in the BRAC case the sustainability notion came as an alternative way to resolve the Bangladeshi citizens' problems, prior to this concept introduced in the Western world.

\section{Microcredit in the major program}

As the public service providing organization, BRAC initiated The Rural Outreach Program and Rural Credit and Training program as an alternative way to fight the poverty, BRAC also lunched the Oral Therapy Extension Program to combat diarrhea in 1979. The Rural outreach and rural credit programs were the kind of exemplary programs of microcredit facility to the rural women of Bangladesh. However, the microcredit program has a long history which used to generate and manage by locals and for locals. Formal microcredit program was begun by ACCION International during the 1970th and implemented on trial basis to Brazil, India, and Bangladesh. In India, formally the Self-Employed Women's Association (SEWA) established the SEWA Bank with the objective of "strengthening its members' bargaining power to improve income, employment and access to social security"4. In Bangladesh formal microcredit program was began by Professor Muhammad Yunus, as an action research program by the students of Chittagong University in 1976, which spread rapidly to 100s of villages. However, Grameen Bank was founded only in 1983, BRAC captured the web length of Professor Muhammad Yunus philosophy about microcredit as a tool to fight against the poverty in Bangladesh, through women empowerment. "BRAC recognized women as the primary caregivers who would ensure the education of their children and the subsequent inter-generational sustainability of their families and households and thereby has been committed to the empowerment of women and education and health of children. Its comprehensive approach combines microfinance under the BRAC's Economic Development program with Health, Education and other Social Development programs, linking all the programs strategically to counter poverty through the livelihood generation and protection. While BRAC believes that micro credit is an important tool in breaking the cycle of poverty, it also places equal emphasis on training its members in income generating activities and facilitating their linkage with consumer markets. Instituting linkages between producers and consumers, BRAC has assisted in the entire process of income generation, juxtaposing itself so as to counter market failures and make it possible for the poor rural producers to be linked to the market for sustainable livelihood"5 (interview with XXXX (2007), Annual report 2006, Homepage 2007, 2016). Here it seems that BRAC has been doing social service delivery in three major sectors (1) heath (2) education and (3) social development with the application of market driven approach to combat with poverty in Bangladesh.

\section{Empowerment of women through integrated development}

Bangladesh is still in the initial stage of socio-economic development. The major problems of Bangladesh are poverty, illiteracy, population growth and natural disaster, along with the unstable politics. Agriculture, sericulture, fishery, animal husbandry, poultry and horticulture are still the major basis for survival. BRAC captures this situation of Bangladeshi from the beginning of its service delivery programs, which are supposed to provide by the government. As evidence, it introduces its poultry vaccination program in 1983, along with other programs such as non-formal primary education program (NFPE), livestock, Rural Enterprises program, income generation for vulnerable group development (IGVGD). By 1986, BRAC rural development program merged to rural credit program with the new focus to reach the poorest of the poor. In the same year, health sector program expanded to address the child mortality issue through the child survival program. BRAC added new monitoring and program evaluation department to examine the intensity of its projects. In 1990, BRAC began send phase of rural development program, with the sustainable rural credit and management development program, where they began to focus mostly human resource development and women empowerment. For the women empowerment program, advisory committee were setup and women health program were initiated, including the establishment of Center for Development Management (CDM). By 1993, BRAC entered the third phase of rural development program with more focus to the women. Same

\footnotetext{
${ }^{4}$ http://www.globalenvision.org/library/4/1051/.

${ }^{5}$ http://www.brac.net/history.htm (BRAC home page 8/09/2017).
} 
year it added a new center 'adolescent reading' to target the adolescent education. BRAC programs get more recognition by then and still continues (BRAC, 2016).

\section{Exemplary model: non-formal education}

In 1993, for the first time the BRAC Non-Formal Primary Education (NFPE) was replicated to African countries. BRAC along with the social development programs (health, empowerment, etc.), began to give more focus on education sector. In 1995 BRAC opened an adult literary center to provide the knowledge about the family planning, pregnancy and child delivery.

The same year BRAC opens four new centers such as Gender Quality Action Learning (GQAL) and Gender Resource Center (GRC), Continue Education and BRAC Health Centers (Shusthyas) including continuation to phase four of rural development programs and Micro Enterprises and Assistances (MELA) program. Until 1997 the BRAC focus was the rural sector development. However, BRAC realized that the Bangladeshi population in the big cities increased and problems exited in the rural areas were equally present in the cities. To target urban poor population, BRAC introduced development programs in the urban areas in 1997. There was no proper policy in the nation to address the Gender issues; therefore, BRAC introduced the gender policy. In the heath service sector BRAC began the Malaria Prevention and Control program with the close coordination with government of Bangladesh. "In Bangladesh, where only $36 \%$ of population have access to primary health care services beyond childhood immunization and family planning, BRAC's Health, Nutrition and Population Program takes a broad approach to the health needs of the poor by providing basic curative and preventive services to more than 97 million people. Trained health workers and volunteers work to raise awareness among the rural poor of health issues that directly impact their lives and families. It seeks to reduce maternal and child mortality and reduce vulnerability to common diseases. Services are offered to control infectious diseases like tuberculosis, acute respiratory infections, diarrhea etc. BRAC has collaborated with the government to immunize children and pregnant women. Under the Essential Health Care program, with the help of Shastho Shebikas (Health Volunteers) and Shastho Kormis (Health Workers) immunization coverage of the population today is $80 \%$. The program also provides services to pregnant women for improving their health and nutrition status. The reproductive health needs of the community in general, with particular focus on BRAC members, are addressed through education on family life, contraception, STD/RTI control, and awareness of HIV/AIDS" (Annual report 2006, BRAC Homepage referred by xxx during the interviews in 2007 and 2016).

\section{Towards institutional building}

In 1997, BRAC established the Legal Aid Clinics in various parts of the country. BRAC also began Chittagong the Hill Tracts Development program in the same year. 1997 was a milestone year to move towards the notion of self-sustain. BRAC establishes the Dairy and Food Project as a business enterprise, local milk producers could sell their product as reasonable price. Now BRAC was not only proving service but also began to play in the economic market sector. Following the same track, BRAC also established Information Technology Institute in 1999. The same year BRAC introduced and established a course on Adolescent Peer Organized Network (APON) to foster the coordination among the adolescent population, including Limb and Brace Fitting Center respectively. By 2001, BRAC presented most of public service delivery sectors such as health and sanitation, social mobilization and empowerment, micro-credit, education and market mobilization.

In 2001 BRAC established a full pledge private University 'BRAC University' and a new commercial bank 'BRAC Bank Limited'. In addition to the establishment of these two major institutions in Dhaka, BRAC also lunched the Post Primary Basic Education Program (PBEn) and Adolescent Development Program (ADP). "Various Support Programs some of which include the Training Division, Research \& Evaluation Division, Advocacy \& Human Rights Unit, Public Affairs \& Communications, Administration \& Special Projects, Internal Audit \& Monitoring, Finance \& Accounting, Publications and Human Resources provide continuous support that is essential to the success and smooth functioning of BRAC's core programs. The Training Division is engaged in all aspects of staff and VO member training, be it poultry rearing or development management. Seventeen residential Training and Resource Centers (TARC) and two BRAC Centers for Development Management (BCDM) have been established by the Training Division. Through its Global Partnership (GP) program, BRAC offers post-graduate diploma in NGO Leadership and Management leading to a Masters degree. Fostering its development principles into its own policies, BRAC's Human Rights 
and Advocacy Unit has undertaken a number of initiatives to promote and protect human rights, particularly that of women" (Annual Report 2006, homepage as referred by xxxx 2007 and 2016 during the interview).

In the social and economic development sector BRAC lunched the ultra poor program, and established the Advocacy and Human Rights unit. Insofar BRAC was not simply a development NGO but became a powerful actor for the social change with the presence of public services delivery sector.

2001 was also the milestone year for BRAC, when it began to work in the foreign country, Afghanistan with the same vision of social empowerment for the first time. In Afghanistan BRAC has been conducting women empowerment, microcredit and education program. "Its programs have been replicated in about a dozen countries including Africa and the Middle East. In 2002, BRAC was registered in Afghanistan to rebuild the ancient country that had sustained decades of conflict and war. Since then BRAC has expanded to 20 out of 34 provinces, providing services in microfinance, health, education, income generation, and small enterprise development. The program takes the best practices of BRAC in Bangladesh and tailors its initiatives according to the needs of the Afghan people. At the end of 2004, BRAC in Afghanistan had 2184 staff, of which 2033 were Afghans" (Interview with xxxx, Annual Report 2006 and home page).

In 2003, the BRAC tuberculoses program covered the entire Bangladesh, it lunched the employment and adolescent program and continued the post primary education program including other initiated programs. In the same year BRAC opened an office with the Ombudsperson to tackle the emerging issues and examine its own position, introduce microcredit program for commercial sex workers. "BRAC operates on the ethical principles and practice and has maintained high levels of transparency in all its operations since it was established. BRAC has been able to maintain an unblemished reputation over the past three decades. The same principles of ethics and integrity that form the supporting pillars of all its activities whether of large scale or small, are also enforced in the organization's policies and practices. BRAC was the first NGO to establish the office of the Ombudsperson in 2004 and also received an Honorary Mention from the Consultative Group to Assist the Poor (CGAP) which recognized BRAC for consistently maintaining high levels of transparency in its annual financial reporting" (Annual Report 2006 and homepage referred by xxxx during the interview 2007).

In addition to that two new institutions were added such as James P. Grant School of Public Health and the Institute of Educational Development. BRAC University added the Center for Governance study in 2005, which within a year was able to produce the report "The State of Governance in Bangladesh 2006". BRAC also opened another enterprise 'BRAC Tea Estates' to be self sustain for its development programs. "BRAC has invested substantially in commercial enterprises one of which is Aarong (retail handicraft chain stores), that links poor rural producers, or in this case artisans, with the expanding urban markets. Such enterprises also include the BRAC Dairy and Food Project which is the second largest liquid milk plant in Bangladesh and has an integrated system of milk procurement from rural dairy farmers to the production of quality dairy products. Six Poultry Hatcheries and three Poultry Feed Mills have been set up to meet the increasing demand for healthy chicks and quality feed in rural areas as well as to provide supply access to women trained in a variety of aspects of poultry rearing. To improve cattle breeds through artificial insemination, BRAC Printers, Cold Storage, Tissue Culture Lab, 15 sericulture process centers, 12 Fish and Prawn Hatcheries, Iodized Salt Factory and Bull Station are also among its Program Support Enterprises. BRAC's Vegetable Export program links poor farmers with international markets and in 2004 received the EUREPGAP Certification from FoodCert Netherlands to export high quality, fresh vegetables to countries under the European Union. Such commercial enterprises not only ensure economic sustainability for poor rural producers, but also earn revenues that the organization can retain to fund its core development programs" ${ }^{\prime}$ (Annual Report 2006, homepage as referred by xxx 2007 during the interview).

BRAC introduced its program in Sri Lanka after the Asian Tsunami in 2005, with the similar approach which it has been applying to Afghanistan. Similarly, BRAC lunched the development program to Tanzania and Uganda. In Bangladesh, BRAC lunched the Maternal, Neonatal and Child Health program. The BRAC ultra poor program was replicated to Haiti and India in 2005 as a powerful option to target the ultra poor people problems. In 2005 BRAC also lunched the Water, Sanitation, Hygiene (WASH) program in Bangladesh.

${ }^{6}$ http://www.brac.net/history.htm (BRAC homepage, 2017). 


\section{Motivation}

BRAC Bangladesh was established with the motivation of rehabilitation and reintegration of refugees in the post war era of Bangladesh. However, as demand increased in the country, BRAC extended its programs and working area. As consequence, it is now one the largest organization in Bangladesh.

"When BRAC [Bangladesh Rural Development Centre] was started in 1972 we thought that it would probably be needed from two to three years, by which time the national government would consolidate and take control of the situation and the people would start benefiting from independence. But as time passed, such a contention appeared to be premature. After 16 years we felt that we have not yet outlived our utility and need to do more and more" (stated by Abed and Chowdhury in 1989, cited by Davis, John K., 2006, p. 2).

In the answer to the journalist question "How did BRAC become the world's largest NGO" to the chairperson of BRAC Mr. Fazle Hasan Abed, he says "The oral rehydration intervention was the BRAC's first national program. Encouraged by its success, I convinced UNICEF to supply vaccines to start a national immunization program. BRAC took charge of mobilizing health workers and immunizing half of the country's children, while the government took responsibility for the other half. In four years, millions of children were vaccinated against childhood diseases. The BRAC's nationwide success with immunization programs gave us tremendous self-confidence. Then we thought:Why not also to take agricultural, educational, healthcareand livestock-related services to the poor? That is how BRAC grew. In the late 1980s, we had about 5,000 staff. By the late '90s, that number was 20,000. Now we have about 48,000 full-time staff in Bangladesh, and that number excludes the staff of the 60,000 one-teacher schools that we run" (Nepali times 358 (20 July $07-26$ July $07^{7}$ ) (The full-time staff number of reached 55,536 by August 2007 and 115,000 by 2017 based on BRAC website).

This short answer provides an example of how dynamic leadership can change the social context and achieve the target.

According to the mission statement "BRAC works with people whose lives are dominated by extreme poverty, illiteracy, disease and other handicaps. With multifaceted development interventions, BRAC strives to bring about positive changes in the quality of life of the poor. BRAC firmly believes and is actively involved in promoting human rights, dignity and gender equity through social and economic, political and human capacity building among the poor. Although the emphasis of BRAC works is at the individual level, sustaining the work of the organization depends on the environment that permits the poor to break out of the cycle of poverty and hopelessness. To this end, BRAC endeavors to bring about change at the level of national and global policy on poverty reduction and social progress. BRAC is committed to making its programs socially, financially and environmentally sustainable, using new methods and improved technologies. As a part of its support to the program participants and its financial sustainability, BRAC is also involved in various income generative activities" (Annual report 2006-2016) and the overall objective of organization is to alleviate poverty and empower the disadvantaged people.

\section{Governance}

The BRAC governing body has twelve persons. "Distinguished professionals, activists and entrepreneurs of excellence repute have been elected to the governing body" (Annual report 2006-16). The members of the governing body are non-executive officials in BRAC. The chairperson Mr. Fazle Hasan Abed who is the founder of BRAC is also chief executive. However, to manage the organization, BRAC has an executive body which comprises chairperson, executive director and managing director of enterprises and two deputy executive directors. In addition to these high levels executive officials, there are sixteen directors who head the various departments of BRAC. To handle large number of programs areas, BRAC has 3054 offices and 22 tanning centers in Bangladesh, where the total number of people 108,741 works full time - 55,536 and 53,205 as BEP teachers (BRAC, 2016).

It has a hierarchical system of management such as head quarter $\leftrightarrow$ regional management $\leftrightarrow$ area management $\leftrightarrow$ branch management $\leftrightarrow$ field workers.

Regarding staff recruitment, Mr. Abed says "We do not pay high salaries. Most of our recruits are from local colleges, people who appreciate our values and share our concern for the poor. Most grow in their roles

\footnotetext{
${ }^{7}$ http://www.nepalitimes.com/issue/358/Interview/13758.
} 
and stay with us for years. We put an emphasis on training, continuous skill development, and value development. Our training centers are always full. Unlike most NGOs, we also do research. We have a large research wing. Creating new knowledge and continuously learning from what worked, what didn't work and why it is important for our growth and success" (Nepali times 358 (20 July 07-26 July 078).

BRAC does not follow a rigid structure of allocating a specific number of employees in each sector; they are recruited as per requirement for the coverage.

\section{Decision making process}

The personnel of each level has given an authority to manage their unit. Staff are empowered to take decisions as they bear the posts. Working procedure manuals and policy documents are the guidelines for office holders. For the internal control, there is an audit department which consists of 137 people of staff. Transparency is maintained both internal and external monitoring and evaluation (program monitoring and evaluation, internal and external auditing).

\section{Funding}

There are two funding sources for BRAC, internal through its major enterprises and international donor agencies. BRAC has two donors' consortia BRAC Education Program and CFPR-TUP (program for ultra poor). The consortia donors are European Commission, Department of International Development (DFID), The Royal Netherlands Embassy, CIDA, Canada, NOVIB the Netherlands, Norway and World Food Program. The consortia meet each other and provide the funding to BRAC based on their own monitoring evaluation report.

The initial source of funding was from the donor agencies, but now its 70\% funds comes from its own major five program supporting enterprises such as BRAC Industries Ltd., BRAC Salt Industries, BRAC Printers, BRAC Print Pack and BRAC Tea Estates. In addition to these major enterprises BRAC has other 15 smaller enterprises such as 488 Aarong Handicraft Production centers, 8 Aarong Stores, 1 Dairy Food Project, 6 Poultry Farm \& Hatcheries, 3 Feed Mills, 15 BRAC Horticulture Nurseries, 8 Fresh Water Prawn Hatcheries, 4 Carp Hatchery, 1 Tilapia Fish Hatchery, 1 Marine Fish Breeding Centre, 21 Seed Production Centers, 2 Seed Processing Centre, 1 Bull Station, 1 Broiler Processing Plant, 67 Chilling Plant, 1 Tissue Culture Lab, 1 Poultry Disease Diagnostic Lab, 1 Feed Analytic Lab, 1 Soil Analytic Lab, 2 Agriculture research Centers, 1 Handmade Paper Production Centre, 6 Sanitary Napkin Production Centre and 1 Delivery Kit Production centre.

In addition to enterprises BRAC has opened five major institutions such as BRAC University (tertiary education), BRAC Bank limited (Financing and Banking, SME financing), bracNet (internet service provider), Documentana limited (Software development) and Delta BRAC Housing Finance Corporation (Housing finance) with the purpose of self sufficiency and socio-economic development of Bangladesh.

\section{Program coverage}

BRAC programs are sprayed to 64 Districts, 509 sub-districts/thanas and 69,421 villages in Bangladesh. Their urban program covers 1097 urban slums. The total estimated population coverage is 110 million. In addition to this BRAC has created 1,790,791 jobs in poultry, 698,426 in livestock, 910,549 in agriculture 89,562 in social forestry, 277,864 in fisheries, 190,181 in horticulture, 25,755 in sericulture, 60,200 in handicraft products 136,159 in small enterprises, and 2,635,212 in small traders, totaling $6,814,699$ (BRAC, 2016).

\section{The contribution of BRAC to change the face of Bangladesh}

\section{The core and subordinates programs}

During 1970-1971, Bangladesh had the war with Pakistan for independence. In that war several people were killed, wounded, and exiled to India. There was no resource with the newly formed government and also there was no such other organization which could help to wounded. Mr. Fazle Hasan Abed took a leadership and formed the Bangladesh Rehabilitation Assistance Committee (BRAC) in 1972 to provide the service to

\footnotetext{
${ }^{8}$ http://www.nepalitimes.com/issue/358/Interview/13758; https://www.insidengo.org/sites/default/files/170120\%20Brac\%20USA\%20Finance\%20and\%20Admin \%20Associate.pdf.
} 
needy people in a form of shelter and health care. BRAC lunched rehabilitation program to returning refugees after the war of independence from Pakistan. As noted above Mr. Abed saw emerging problems such as health, illiteracy and poverty in Bangladesh and further expanded its program to address those issues. His leadership brought BRAC in today's condition "BRAC is a one of the biggest public services provider organization in the world". Despite massive development work through government agencies, international organizations and NGOs like BRAC, Bangladesh is still facing serious problems such as population growth, poverty, illiteracy, unemployment. In addition to these major issues, Bangladesh is also suffered from natural calamities. Another problem of Bangladesh is political instability and lack of governance. In comparison to government organizations, nongovernmental organizations are stable and efficient in public service delivery in Bangladesh. In this context, the role of development organizations like BRAC is growing.

\section{Priorities}

BRAC prioritizes poverty alleviate as a major agenda followed by empower people through sustainable development at national, zonal, district and village levels.

To address major problems such as population growth, poverty, illiteracy, unemployment and health, BRAC has developed four major core programs such as economic development (through microcredit, employment generation, entrepreneurship), health program (vaccination, TB, women health, sanitation etc), education program (primary, post primary, adult, women and tertiary), social development, human rights and legal services. In addition to its core program BRAC has nine support units such as training, administration and risk management, advocacy and human rights, finance and account, human resource, procurement, estates and management, public affairs and communications, publications and research and evaluation. Through these units BRAC manages its various programs to the entire country.

Economic development program is the largest program, where until June 2007; BRAC has dispersed US\$ 4,160.66 as microcredit, which covers 220,006 Village Organization (VO), 6.37 million VO members, 5.57 borrowers. This large dispersement is carried out through its Regional Offices (28), Area Offices (312) and Branch Offices 2842. Likewise, in health program BRAC has 68,045 active health volunteers who cover 31 million population. BRAC tuberculosis program covers 83.2 million population (BRAC, 2016).

BRAC also equally works for social development and social justice as well and for human rights. To provide such services, BRAC has formed 12183 Polli Samaj (legal and advisor society), 45350 Polli Samaj Leaders are trained, 739 Samaj unions formed. To make aware about the social justice BRAC has staged 78389 Popular Theatres. Likewise, in education sector development BRAC have 49 Area Offices, 655 Branch Offices, 32,000 Primary Schools, with more than 1 million students, so far 3.67 million students are graduated. BRAC also have 20,140 Pre-Primary Schools where 0.56 million students are studying. For the adolescent girls education, they have 8,538 centers in the country (BRAC, 2016).

\section{Relationships with the government}

In the answer to the journalist question "Persuading the government to help you must have been easy, since your work would reach out to millions", the chairperson of BRAC Mr. Fazle Hasan Abed says "Not quite. To reduce the rate of infant mortality, I needed to purchase vaccines from abroad. I needed fridges in villages to store the vaccines, but most rural regions were not electrified. I needed all the healthy workers in the country mobilized to administer the vaccine. But the government said, "We have waited thousands of years for vaccination. Why don't we wait for five more years when all the villages will have electricity? Meanwhile, you can do something else." So, we visited households door-to-door - 13 million of them! - to teach village women how to make oral rehydration fluids by themselves with salt, sugar, and water in the right ratios. This bit of simple knowledge had the potential to save lives every year" (Nepali times 358 (20 July 07 - 26 July $07^{9}$ ). This statement raises two basic points (1) efficiency of BRAC (2) inefficiency of the government work. This account also shows how insincere the government was in service delivery.

BRAC works very closely with the government on the implementation of various projects, such as poverty elevation (through microcredit, employment generation, entrepreneurship development, vocational training, this program has been performed in 36 districts our of 64 , which is $56 \%$ of coverage), health (one of the BRAC's core program is to provide health service to the poor, they have varieties of programs such as vac-

\footnotetext{
${ }^{9}$ http://www.nepalitimes.com/issue/358/Interview/13758.
} 
cination, tuberculosis, maternity health, children health and awareness campaign for HIV/AID, diarrhea and malaria, smallpox etc.), education (from pre-primary to tertiary education, adolescent education, literacy program for women and men etc.) social empowerment (legal and human rights training and advocacy) and disaster management. BRAC also works closely with the government in water supply and sanitation.

Dr. Imran Matin, Director of Research \& Evaluation Division, says that the role of civil society in Bangladesh is very different from other countries. He says Bangladeshi politics is not stable and the government programs are not properly managed. However, NGOs like BRAC also cannot handle the massive poverty, illiteracy, natural disaster (floods, cyclones), so civil society and government both needs to work together. He states that Bangladesh is a living example of collaborative approach, particularly in health, education and economic development work. Executive director Dr. Mahabub Hossain states that Bangladesh government's governance mechanism is favorable to NGOs for program implementation. He gives focus on apolitical nature of BRAC which gives more ground to work in the collaborative way with the government (interviews on 2007 quoted with permission).

Both senior officials pointed that government is not stable and is not capable enough to tackle the serious problems theat Bangladesh has been facing. It seems that the inefficiency in government mechanism has both positive and negative effects in NGOs stand. One negative side is monitoring and evaluation of the ongoing program and another is repetition of similar programs from different NGOs. However, there are contradictory views among the senior and mid level personnel of BRAC. Mid-level staff mentioned that government never monitors what NGOs are doing. It seems that government of Bangladesh is not able to provide the public services such as education, health and support the poor people through the credit facility. NGOs like BRAC provide such services; and the there is no sufficient ground for the government to challenge the NGOs stand, therefore, government of Bangladesh tries to make favorable environment with NGOs (Interview with $\mathrm{xxx} 2007$ ).

Bangladesh case fits exactly what M. Shamsul Haque (2002) points in reference to power mechanism of NGOs and government in Bangladesh. He states that "There are serious implications of this for states in many developing countries, especially regarding a restructuring of power shared between governments and NGOs. In recent years, compared to major government agencies, NGOs have gained prominence in terms of their societal roles, public image, and capacity to command external support. More specifically, while the scope of the public sector is being reduced, government spending is diminished, and state agencies are discredited, NGOs have proliferated, their membership has increased, and the assistance they receive from external agencies has multiplied. In fact, the local institutional linkages of government have been weakened by the growing networks of NGOs. Moreover, a multitude of new concerns - including basic needs, human rights, gender equality, the environment, and sustainable development - have assigned greater power to NGOs while rendering the role of government relatively obsolete and even unwelcome in addressing these new issues" (p. 412).

However, it does not mean that NGOs are free to lunch any program they want. There is a regulatory body in the government mechanism. NGOs need to register with the government agency and have permission from the government to get foreign funds. Once NGOs get permission or approval for the foreign funding, government is not efficient enough to trace where that funding is going and how NGOs utilize the resources.

\section{Regulatory relationship with the government}

The Government of Bangladesh still uses various acts to regulate the civil society organizations, which were developed by British colonial government, such as the Societies Registration Act of 1861, the Trust Act of 1882, and the Cooperative Societies Act of 1925 still used for the registration of NGOs. In addition to that the act developed by Pakistan " The Voluntary Social Welfare Agencies Ordinance of 1961", which still allows the government (especially its department of social welfare) to authorize or suspend NGOs. This train of control over the NGOs by the government continued after the post-independence period as well such as Foreign Donations (Voluntary Activities) Regulation Ordinance was passed in 1978. NGO Affairs Bureau (NGOAB) was created in 1990, and the Association of Development Agencies in Bangladesh (ADAB) was established in 1974. NGOAB is supposed to maintain and control NGOs through the assessment of their performance, approval of their projects and expatriate appointments, monitoring their programs, and inspection of their incomes and expenditures. The NGOAB is a powerful government institution, who has the right to reject any application for creating new NGOs, and terminate the registration of existing ones. NGOs like 
BRAC are members of the Association of Development Agencies in Bangladesh (ADAB), is supposedly the umbrella organization for the development NGOs in Bangladesh, which is major actor to coordinate and facilitate the relationship and interaction among NGOs, between the NGOs and the government, between the NGOs and the donors, and between the NGOs and other civil-society groups (Haque, 2002, p. 418).

Insofar there is not much tension between NGOs and government; however, accountability and transparency question are raised from both sides. BRAC officials say that NGOs who get the funding from foreign agency most show the detail account of expenditure to the government of Bangladesh as well as to the donor agencies. BRAC claims that they became one the biggest organization because of transparency and accountability to the government, its members and partners. They state that BRAC has been a collaborative partner to the government of Bangladesh since its inception and providing inputs to the governments of five years plans (Interviews with xxx 2007).

"The government attitudes have been found to be ambivalent. While on the other hand, the government in their successive five-year plan categorically emphasized the participation of NGOs in national development, they, on the other hand, promulgated a number of regulatory laws to control NGO activities, inhibiting their smooth operation. The government bureaucracy and political elites tend to exhibit a strong bias against the NGOs and most often create bottlenecks to impede their activities. Perhaps, this may be attributed to the very nature of the government and existing socio-economic and political structures which have been mostly autocratic and non-democratic in nature. However, in recent years, there have been some collaborative national ventures which have been successfully undertaken by both NGOs and the Government" (Asian NGO Coalition for Agrarian Reform and Rural Development, 1994). The government of Bangladesh has recognized the NGOs role in national building evidence can be traced through growing recognition of NGOs in the two national development plans, including the Second Five Year Plan (1980-1985) and the Third Five Year Plan (1985-1990). Many NGOs were increasingly considered as collaborative partners of the government to implement programs undertaken in both the Fourth Five Year Plan (1990-1995) and the Fifth Five Year Plan (1995-2000) (Haque, 2002). However, BRAC officials state that there is no input from the government side to the NGOs work, but NGOs provide supports to the government through their program, advocacy and publications.

\section{NGOs power relation with the government in Bangladesh}

The above account shows that NGOs are powerful stakeholders. There are cases of growing power relation to the Government (Haque, 2002). Haque shows five indicators of growing NGOs power in Bangladesh, he states (1) a crucial indicator of the expanding power of NGOs is their takeover of some of the basic activities that used to be performed by various state agencies. He gives the following examples such as large development NGOs such as BRAC, Grameen Bank, Proshika, and ASA have become credible institutions to provide varieties of inputs and services related to microfinance, small industry, livestock, fisheries, sanitation, basic education, and health care. In addition, the state monopolies like telecommunications, printing, and computer software are already being threatened by some of the largest NGOs, and it is expected that they may get involved in other sectors such as gas and mineral resources. This trend implies a diminishing role for government ministries and agencies in such sectors and activities (pp. 420-421). This explanation exactly fits with mentioned NGOs case. For example, BRAC has fifteen enterprises, four institution for selfsufficiency.

The Haque's second indicator of growing NGOs power of the most large NGOs members can affect the political power structure. Most of their members are women who represent a formidable political force as a group participating in elections and shaping the election outcomes (especially at the local level). The Haque's point is valid because BRAC itself has 110 million populations through its program and has country wide coverage. It has country wide networks of enterprises. There are also several NGOs like BRAC such as Grameen Bank, Proshika, and ASA, Nejekori etc. Those organizations also have similar networking relationships with its members. Therefore, NGOs power in Bangladesh cannot be avoided. A third point is about the NGOs involvement in advocacy and publicity. Because of NGOs countrywide networks they can influence government for their favor. The Forth point at Haque tables is NGOs direct involvement in macro level political processes such as educating voters and affiliating with national political parties. The Haque's final point is growing economic power of NGOs in Bangladesh. The author totally agrees with the Haque's notion of power politics, because some of the NGOs of Bangladesh are internationally well-known and ap- 
ply their model for socio-economic development. Bangladesh is one of the poorest country in the world and such countries are highly dependent with the international donation.

Haque also argues that NGOs power also grows with the local people, because NGOs provide the goods and services from the government. NGOs make strong relationships with the local through membership expansion. For example, BRAC has more than 3.5 million members, covers all 64 districts through its programs, has 108,741 employees, owns own Bank, University, and internet hub. These accounts surely give BRAC a great deal of power to make good connection with people. Likewise, Grameen Bank has 2.3 million borrowers and more than 10000 employees in 35000 villages, Proshika has 1.9 million members and borrowers, Swanirvar Bangladesh and ASA Bangladesh, each have more than 1 million members (Haque, 2002). These large numbers of population of Bangladesh provide the legitimacy of NGOs services and provides a power to NGOs at local level. These NGOs are also creating popular images through their comprehensive programs such as health, education, training and microcredit facility. In the other hand, the government of Bangladesh tries to work on the collaborative approach with NGOs. Haques states that "This shift in government policy from controlling NGOs to forming partnership with them, implies the state's diminishing role and the growing significance and power of NGOs" (p. 422). Another force helping NGOs power growth is the policy of donor agency. The World Bank, IMF, Asian Development Bank and other multilateral donor agencies help to increase the NGOs power in the developing world, which completely fits with the Bangladesh case as well. Most importantly the World Bank, the International Monetary Fund, the International Finance Corporation, the Asian Development Bank, the World Food Program, and the UN Economic and Social Council and European Union are the major donors of Bangladesh. These agencies put pressure on the governments of developing nations to use NGOs as an instrument of good governance, and recognize them as legitimate players in global politics (Haque, 2002, p. 424). These international agencies also help NGOs to become more powerful and help to reduce the government power.

Relationships with international organizations. BRAC invites partnership from international organizations in various projects and they also have international organizations as our donors.

Relationships with local bodies / individuals. BRAC encourages universal participation in local bodies.

Sustainable development. All our core programs are interrelated and geared towards sustainable development. However, under the BRAC's microfinance program, the borrowers receive a range of trainings, technical assistance and other services to market their finished goods. BRAC has also set up a number of enterprises (pp. 17-18) to support its development programs and the profits generated from these enterprises are diverted back to the BRAC's poverty alleviation programs.

\section{Conclusion}

Because of the lack of the economic resources and weak governance, Bangladesh has been facing various serious social problems such as poverty, illiteracy, population growth. Likewise, due to its geographical location it has been facing problems caused by nature (cyclones, flood and diseases) (Haque, 2002). Bangladesh also faces the problems connected with the weak governance. There has been instability in the government, inter party struggles inside parties and frequently military role which sometime leads towards violence. Political leadership most often concentrates on personal or party benefits therefore general pubic have been lacking the focus from the authority. This tendency is not a new phenomenon in developing world context, where general pubic normally do not get desired, required (necessities) public goods and service from the authority. Bangladesh is fits on this line, where government has been lacking to address the socioeconomic problems of its citizens (health, food, shelter, education and security) and is inefficient to tackle with the natural crisis (which occurs every year in monsoon). The interviews participants of this research from BRAC, Kumudini and local people as well as documentary evidences (World Bank, 2005; Haque, 2002; Gauri and Galef, 2005; Hasan, 1992; 1993) assure that normally, citizens' expectations have been neglected even since before the British colonized to the Bangladesh. Public service deliveries (such as health facility, food, shelter, education, employment, sanitation, hygienic water etc.) to the citizens are not properly regulated from the government since the British colonial period (1858 to 1947), Pakistani rule (1947-1971) and independent government of Bangladesh since 1971. However, there is a long tradition of collaborative approach to tackle the local social and economic problems through individuals, groups and civil society organizations participation. Therefore, the presence of nongovernmental organizations to resolve the local problem and public service delivery is not new phenomena in Bangladesh. In another world, NGOs concept 
for the social development as western world or rest of world views as a new approach does completely apply to the Bangladesh case. There were formal and informal local bodies, voluntary social organization and civil society organizations and few NGOs in Bangladesh even when the British colony was functioning; and this trend, continued in the Pakistani regime, followed by the independent state of Bangladesh. However, the formal NGOs mushroomed rapidly since 1980 onwards, which still continues in Bangladesh. This is a clear indication that acceleration of civil society movements in Bangladesh has significant relationships with the global free neo-liberal economic movements of the world.

This study clearly shows that NGOs gain more power, which ultimately hollowing the state's role. In relation to diminishing power of state and power increment of NGOs in it can be argue in two major frame (1) it is happening because of inefficiency of government. The government of Bangladesh has not been able to provide public goods and services to its citizens. As alternatives, people look for possible options to overcome from the social and economic problems. As a consequence, civil society leaders began to mobilize the available resources to resolve the problem. Altruistic and voluntarism traditions helped people to formulate civil society organizations, cooperative firms and NGOs to solve problem through their own way and reach. Civil society organizations reached to the people efficiently therefore, NGOs gained more power and trust locally, which help in thinning the role of the government in the public eyes. Another reason of hollowing the state power is (2) due to the civil society's growing recognition locally as well as nationally and in the international space. In a short span of time, Bangladeshi NGOs became popular stakeholders for the social mobilization, because of their popular programs such as microcredit, health and sanitation, education and women empowerment, enterprises development and training, and advocacy on human rights and women rights. These programs directly reached to the poor and have positive impact to the day to day life poor citizens. Because of modern advance communication technology their model of social and economic development spread throughout the world which has been copied and implemented in many developing countries. This recognition attracted the many donors' agencies including bi-lateral and multi lateral organizations. Such donor agencies raised their investments directly to the Bangladeshi NGOs, which used to go through government agencies. These new phenomena of funding and recognition made NGOs more independent and gained more power than they have before. Another strength NGOs gained in Bangladesh is through its memberships and employment generation. NGOs provide employment to the large number of people in their offices and also employment options through their collaborative field programs. These members give power to the NGOs even in political lobbying. For example, ASA has 4.18 million members through its microcredit program, BRAC programs cover 110 million people, Grameen Bank is operating in 79,925 villages, has 2,462 branches and 24,592 operational staff and 7.31 million borrowers, 97 per cent of them are women, and PROSHIKA has programs in 18,898 villages have several million members. Likewise, Nijera Kori has 232,228 group members. There are about 1250 NGOs who have a large number of memberships. This clearly shows that NGOs become more and more powerful and state becoms weaker.

BRAC is the biggest NGO in Bangladesh in terms of financial stand, staff, programs and memberships. Mr. Abed says "Microfinance is BRAC's largest program. This year, we have given out $\$ 900$ million to 6 million borrowers, most of whom are women. Next year, we expect to give out more than a billion dollars as loans. Our borrowers meet our staff every week to pay their installments. What we have done is connect our loans to income-generating activities. For instance, a borrower may buy a cow that gives her two liters of milk a day. She may sell that milk to her neighbor at 7 taka per liter (1 US Dollar equals, 81.45 Bangladeshi Taka, exchange rate noted on September 5, 2017). But I know I can sell that milk at higher prices in urban areas. BRAC collects milk from her at 18 taka, pasteurizes and packages it, and sells it in Dhaka at 30 taka per liter. Both the borrower and BRAC make money providing a product to the market. Similarly, a woman may borrow 5000 taka to buy vegetable seeds. But she can't find high-quality vegetable seeds. BRAC produces high-quality seeds, which it then sells to her. Over time, with higher yields and higher sales, her income goes up, and that raises her family's quality of life. In poultry, too, we give out high-quality day-old chicks, and have trained women to offer vaccination services in villages. Our chicken lays 240 eggs a year compared to the 40 a year a deshi bird lays, thereby fetching farmers more money. We thus see microfinance as a tool to raise the income and quality of life of the poor by connecting them to the market" (Nepali times 358 (20 July $07-26$ July $07^{10}$ ). This short description provides how deep a nonprofit organization can reach to the everyday lives of its citizens. Providing free education is another program. Regarding edu-

\footnotetext{
${ }^{10} \mathrm{http}: / /$ www.nepalitimes.com/issue/358/Interview/13758.
} 
cation, Mr. Abed says "Of the 19 million Bangladeshi children, 16 million are enrolled in schools. Of the remaining 3 million, BRAC has taken in about 1.6 million as students at its one-teacher schools. The model is that we have one teacher for about thirty children of different ages and skills". This account clearly shows that the presence of NGOs in public services delivery or development works of Bangladesh. This notion certainly reduces the government power and raises the worthiness of NGOs. Bangladesh is a good example, where private organizations, NGOs strength the capacity and on the other hand the government mechanism lackes its trust at least at a local level efficiently when NGOs show exemplary works. The western notion of hollowing the state means "the privatization and limiting the scope and forms of intervention, the loss of functions by central and local government departments to alternatives delivery systems (such as agency)" (R.A.W. Rhodes, 1996). In the Bangladesh case, the World Bank, IMF, the Asian Development Bank and other multilateral donor agencies ask to the government to reduce its power in service sector delivery, which is ultimately thinning the state authority. Moreover, the growing legitimacy and trustworthiness of NGOs in Bangladesh are more powerful to diminish the government power because of their efficient working modalities (based on the discussion with the experts in Dhaka, 2007, 2016).

\section{Declaration}

Interview was taken with the interviewees approval (Informal consent forms were filled prior to interviews or discussion of focus groups. Even though, an anonymous approach is also applied. In some cases, respondents' names are used as $\mathrm{xxxx}$ ).

\section{Acknowledgement}

The author acknowledges that this study was partly funded by the Department of Sociology, Syracuse University and his dissertation supervisor Prof. Steven R. Brechin (during his studentship in 2005-2012). He thanks Mr. Abul Ansari who voluntarily accompanied with me during the fieldwork, who worked as an interpreter as well as made all connections with the NGOs leaders in Dhaka, organized field trip during the flooding season. It was impossible to conduct this study without his involvement. He would also like to thank Ms. Pushpita Alam and Mantasha Ahamed who coordinated our meetings with various officials in BRAC. We would also thank to all officials and local people who participate during the interviews processes. He would also like to thank Ms. Prajita Bhandari for her insightful thoughts and comments on the paper, without her support this research was impossible. He also thanks to Manaslu; Prameya and the reviewer panel for their input and comments.

\section{References}

1. BRAC (2016). Annul report, BRAC, Dhaka. Available at http://www.brac.net/images/reports/2016/ Bangladesh-Annual-Report-2016.pdf.

2. BRAC (2013). Annul report, BRAC, Dhaka.

3. BRAC (2006). Annul report, BRAC, Dhaka.

4. ASA (2005). Annul report, Dhaka.

5. Grameen Bank (2005). Annual report, Dhaka.

6. PRISHIKA (2005). Annual Report, Dhaka.

7. Kumudini Trust (2005). Annual Report, Dhaka.

8. Nejera Kori (2005). Annual Report, Dhaka.

9. Government of Bangladesh (2006). Statistical Pocket Book, Dhaka.

10. Gauri V., Galef, J. (2005) NGOs in Bangladesh: Activities, resources, and governance. World Development, 33(12), 2045-2065.

11. M. Shamsul Haque (2002). The Changing Balance of Power Between the Government and NGOS in Bangladesh. International Political Science Review, 23, 411.

12. Davis, John K. (2006). NGOs and Development in Bangladesh: Whose sustainability counts? Global Poverty: Sustainable Solutions. Proceedings of the Anti-Poverty Academic Conference with International Participation, Institute for Sustainability and Technology Policy, Murdoch University, Perth.

13. A Country Paper of Bangladesh (2006). Promoting Dialogue and Collaboration in Sustainable Agriculture \& Rural Development (SARD) Between NGOs/RPOs and Government, Food and Agriculture Organization of the United Nations (FAO-UN) by Asian NGO Coalition for Agrarian Reform and Rural Development, Manila, Philippines. 
14. Joseph Devine (2003). The Paradox of Sustainability: Reflections of NGOs in Bangladesh, Annals of the American Academy of Political and Social Science, 590, Rethinking Sustainable Development, 227-242.

15. Samiul Hasan (1993). Voluntarism and Rural Development in Bangladesh. Asian Journal of Public Administration, 15(L), 82-101.

16. Samiul Hasan (1992). Voluntarism and Rural Development in Bangladesh. The Asian Journal of Public Administration, 15(01), 82-108.

17. Samiul Hasan, George Mulamoottil and John E. Kersell (1992). Voluntary organizations in Bangladesh: a profile, Environment and Urbanization, 4, 196.

18. World Bank (2016). The World Bank in Bangladesh. Available at http://documents.worldbank.org/curated/en/264111487858247532/pdf/112979-WP-PUBLIC-WB-ProjectProfiles-7Feb17.pdf.

19. The World Bank (2006). Economics and Governance of Nongovernmental Organizations in Bangladesh, Report No. 35861-BD, Poverty Reduction and Economic Management Sector Unit South Asia Region. The World Bank.

\section{Appendix 1.}

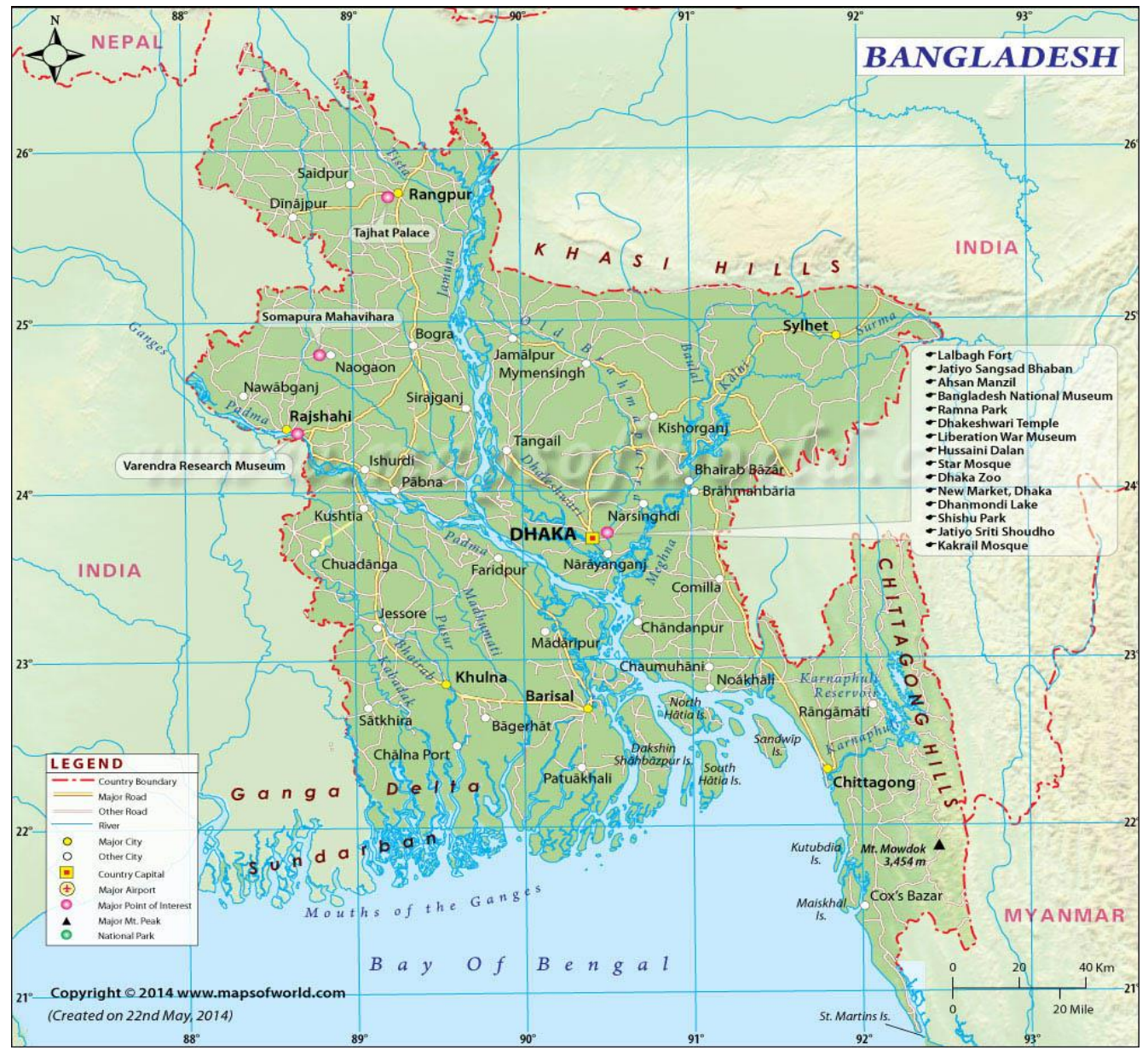

Figure 1. Political division of Bangladesh

Sources: BRAC annual report and Map of the world.com, http://www.mapsofworld.com/bangladesh/bangladesh-political-map.html.

Appendix 2. Some of the important information about BRAC Bangladesh can be seen on 2016 Annual Report - http://www.brac.net/sites/default/files/annual-report/2016/Bangladesh-AnnualReport-2016.pdf.

To get clearer picture of BRAC Bangladesh, author request readers to view following websites as well.

Naomi Hossain and Anasuya Sengupta (2009). Thinking Big, Going Global: The Challenge of BRAC's Global Expansion. IDS WORKING PAPER 339, Institute of Development Studies at the University of Sussex Brighton BN1 9RE UK http://onlinelibrary.wiley.com/doi/10.1111/j.2040-0209.2009.00339 2.x/pdf. 
http://bracnet.net/our-network-coverage/.

http://www.brac.net/.

http://www.jointlearningnetwork.org/resources/mapping-and-documentation-of-work-processes-in-the-bracand-ssk-health-secu.

http://www.wpro.who.int/asia_pacific_observatory/hits/series/bgd_health_system_review.pdf Bangladesh health system review (Health Systems in Transition, 5(3), 2015).

http://www.bracinternational.nl/en/. 